\title{
PROGRAM OPERASIONAL PNPM MANDIRI PERKOTAAN DI KOTA BANDAR LAMPUNG: KAJIAN TENTANG PELEMBAGAAN (FORUM) MUSYAWARAH
}

\author{
Noverman Duadji \\ Jurusan Administrasi Negara Fakultas Ilmu Sosial dan Ilmu Politik Universitas Lampung \\ Jl. Sumantri Brodjonegoro Nomor 1 Bandar Lampung \\ E-mail:novermanduadji@yahoo.co.id
}

\begin{abstract}
Abstrak Rumusan masalah penelitian ini adalah 'Bagaimana pelembagaan (forum) musyawarah sebagai media partisipasi masyarakat dalam permusan dan implementasi program operasional PNPM Mandiri Perkotaan di Kota Bandar Lampung?'. Penelitian bertujuan untuk mendapatkan gambaran tentang bentuk pelembagaan (forum) musyawarah dalam perumusan dan implementasi program operasional PNPM Mandiri Perkotaan di Kota Bandar Lampung, sedangkan metode yang digunakan adalah metode kualitatif. Berkaitan dengan hasil penelitian diperoleh kesimpulan bahwa LKM dan KSM merupakan bentuk pelembagaan (forum) musyawarah dalam permusan dan implementasi program operasional PNPM Mandiri Perkotaan di Kota Bandar Lampung. Forum ini masih bersifat simbolik. Artinya forum musyawarah masih dikondisikan oleh pemerintah dengan mekanisme pembentukan bersifat top down, keanggotaannya cerminan representasi elit (elitis) bukan representasi masyarakat miskin dan demikian pula dengan keikutsertaan warga masih terkesan sebagai partisipasi semu. Kondisi inilah yang menyebabkan substansi program aksi PNPM MP di Kota Bandar Lampung belum menyentuh akar persoalan kemiskinan warga kota. Program aksi baru mampu mengatasi fenomena (gejalah) yang muncul atau 'symptomatic program' dan belum mengarah kepada 'strategic program'. Program operasional belum beorientasi atau berpihak pada rakyat miskin sebagai sasaran (pro poor policy), tetapi masih menunjukkan kehendak dan keinginan pemerintah. PNPM Mandiri Perkotaan Kota Bandar Lampung belum menunjukan program aksi (kebijakan) hasil dari pelembagaan (forum) musyawarah atau sebagai hasil proses deliberasi, tetapi lebih merupakan 'in policy', yaitu kebijakan inkremental, tambal-sulam atas kebijakan sebelumnya dan lebih mencerminkan kepentingan pemerintah. Ada dua saran yang menjadi masukan untuk ditindak-lanjuti oleh pemerintah kota guna meningkatkan kualitas kebijakan (program), yaitu: (1) perlu merumuskan rancangan kelembagaan (forum) musyawarah yang benar-benar mencerminkan hakekat musyawarah yang sesungguhnya dengan dilandasi kerangka legal formal yang mengatur partisipasi publik kedalam bentuk perencanaan partisipatif; dan (2) perlu menumbuh-kembangkan nilainilai demokrasi perencanaan melalui kerjasama nyata, pembinaan manajerial, dukungan finansial dan penguatan jejaring (networking) kemitraan dengan organisasi akar rumput sebagai wadah masyarakat.
\end{abstract}

Kata Kunci: Musyawarah; Partisipasi Masyarakat

\section{OPERATIONAL PROGRAM PNPM URBAN IN BANDAR LAMPUNG : STUDIES ON INSTITUTIONALIZATION ( FORUM ) DELIBERATION}

\begin{abstract}
The research problem is 'how to institutionalize deliberation forum as public participation media in formulating and implementing the action program of the National Program for Community Empowerment (PNPM Mandiri)?'. The research aims to get an overview of the form of institutionalization (forum) deliberation in the formulation and implementation of operational programs PNPM Urban in Bandar Lampung, while the method used is qualitative method.The conclusion, that the LKM and the KSM is a form of institutionalization (forum) deliberation in formulation and implementation of operational programs of the National Program for Community Empowerment (PNPM Mandiri) in Bandar Lampung. This forum is still largely symbolic. This means discussion forum still conditioned by the government with the formation mechanism is top down, its membership reflects the representation of elite (elitist) is not representative of the poor and so it is with the participation of citizens still seem as apparent participation. This condition causes the substance of the action program did not touch the root of the problem of poverty citizens. The new action program is able to cope with the arising phenomenon or 'symptomatic programs' and yet lead to 'strategic program'. The operational programs are not oriented to the poor or pro-poor as a target, but it still shows the will and desire of the government. There are two suggestions that becomes the input for further action by the city government in order to improve the quality of the policy (program), namely: (1) The need to formulate institutional design (forum) deliberation that really reflect the true nature of the deliberations based on a formal legal framework governing public participation in the form of participatory planning; and (2) the need to grow and develop democratic values through the planning of real cooperation, managerial coaching, financial support and strengthening networks (networking) partnerships with grassroots organizations as a forum for the community.
\end{abstract}

Keywords: Deliberation, Public Participation

\section{PENDAHULUAN}

Hingga saat ini, kemiskinan merupakan musuh nyata terbesar yang dihadapi Bangsa Indonesia. Sama halnya dengan kondisi yang terjadi di Kota Bandar Lampung dimana dari jumlah penduduk
879.651 jiwa, 31,43\% (276.474 jiwa) terkategori miskin. Upaya penanggulangan kemiskinan telah mendapat perhatian dari pemerintah daerah (provinsi dan kota) maupun dari pemerintah pusat. Pemerintah Provinsi Lampung mengeluarkan program andalan 
daerah, yaitu (1) Program Pemberdayaan Kampung Tua dan (2) Program Desaku Maju Sakai Sambayan. Sementara Pemerintah Kota Bandar Lampung mengeluarkan program ekonomi kerakyatan (ekor) dengan sebutan Gema Tapis Berseri (Bappeda Propinsi Lampung, 2010). Pemerintah pusat juga telah banyak mengeluarkan program serupa, misalnya: PPK, PNPM-P2KP, PARUL, P2SEM, Gerdu-Taskin; dan bahkan sebelumnya ada Program JPES; BLT, serta program serupa lainnya.

Hal yang menarik untuk dicermati, kendati dalam makna jumlah dana semakin meningkat dan semakin bervariasinya program penanggulangan kemiskinan dan pemberdayaan masyarakat miskin, tetapi faktanya dari konteks sosial ekonomi, berbagai program tersebut belum membuahkan hasil sesuai harapan. Masyarakat miskin masih saja terbelit oleh persoalan kemiskinan. Kebijakan selama ini belum terlalu banyak memberikan manfaat dan secara substansi lebih mencerminkan kehendak pemerintah ketimbang mengakomodasi kebutuhan masyarakat miskin yang merupakan target group kebijakan tersebut. Mungkin saja, kondisi ini sebagai akibat dari simplifikasi dari pernyataan Thomas R. Dye dalam Islamy (1986:18) yang memaknai kebijakan sebagai "what government choose to do or not to do".

Memang benar adanya, pemerintah memiliki kendali otoritas untuk berbuat atau tidak berbuat sesuatu. Namun, pernyataan ini seolah-olah mentolerir tindakan apapun bisa dilakukan pemerintah, yang tentu saja menyamarkan makna fundamental mengenai mengapa kebijakan itu diambil. Kebijakan publik tidak dapat dimaknai hanya sebagai otoritas penuh pemerintah untuk berbuat sesuatu atau sekedar melaksanakan otoritas rutin yang melekat itu. Konteks dan substansi kebijakan publik harus mencerminkan upaya (solusi) pemerintah untuk mengatasi permasalahan riil yang dihadapi masyarakat atau untuk memenuhi kebutuhan masyarakat. Jika demikian, maka tentu saja antara pemerintah dengan masyarakat yang menjadi subyek kebijakan perlu bekerjasama. Pemerintah perlu melibatkan masyarakat, dan begitu juga sebaliknya masyarakat harus memiliki kesadaran untuk berpartisipasi aktif dalam perumusan dan implementasi program. Karenanya pada konteks penelitian ini, yang menjadi sentra perhatian adalah pelembagaan (forum) musyawarah yang menekankan fungsi penting partisipasi publik dan partnership diantara para stakeholders kebijakan dalam perumusan program operasional untuk menjamin: (1) terbukanya peluang rakyat berpartisipasi; (2) identifikasi masalah dan akar persoalan kemiskinan rakyat menjadi terpetakan; (3) terjadinya interaksi, kerjasama antara state-people sehingga tanggungjawab bersama tumbuh, berkembang dan semakin kuat; serta timbulnya kepercayaan dan rasa memiliki masyarakat terhadap program operasional. Akhirnya, kebijakan (program) yang dihasilkan akan dapat mencapai sasarannya, yaitu menurunnya angka kemiskinan dan meningkatnya kesejahteraan masyarakat di daerah perkotaan.
Sejalan dengan uraian diatas, maka rumusan masalah penelitian ini adalah Bagaimana pelembagaan (forum) musyawarah sebagai media partisipasi masyarakat dalam permusan dan implementasi program operasional PNPM Mandiri Perkotaan di Kota Bandar Lampung?. Penelitian ini bertujuan untuk mendapatkan gambaran tentang bentuk pelembagaan (forum) musyawarah sebagai media partisipasi masyarakat dalam permusan dan implementasi program operasional PNPM Mandiri Perkotaan di Kota Bandar Lampung.

\section{METODE}

Metode merupakan tools (alat) penelitian. Pemilihan metode disesuaikan dengan apa yang ingin dicari dan apa yang ingin diketahui. Terkait dengan ini, maka ada 2 hal yang menjadi pertimbangan: (1) obyek kajian; dan (2) rumusan masalah yang diteliti. Penelitian ini menggunakan metode kualitatif. Peneliti melakukan investigasi fokus kajian tentang desain (konteks dan konten) program yang merupakan tindakan dan penjabaran aktor kebijakan (pemerintah) Kota Bandar Lampung dan stakeholders terkait mengenai PNPM Mandiri Perkotaan (kebijakan pemerintah pusat), dan kemudian mengkaitkannya dengan mekanisme partisipasi yang dilakukan kelompok sasaran (target group). Relevansi penggunaan metode kualitatif dalam penelitian ini adalah untuk membongkar dimensi yang tersembunyi tentang konteks dan konten program PNPM Mandiri Perkotaan Kota Bandar Lampung sebagai hasil interaksi policy stakeholders.

Key informant yang dipilih bukan didasarkan pada keterwakilan, namun lebih kepada kompetensi dengan mempertimbangkan: a) subyek yang benarbenar terlibat, dalam arti mengetahui, melihat, mendengar, berbuat serta memahami infomasi yang berkaitan dengan substansi kebijakan dan program PNPM mandiri perkotaan; b) informan dengan keikhlasan, senang hati, terbuka dan jujur dalam memberikan data-data yang diperlukan; c) teknik snow-ball, yaitu menggulirkan informan awal secara berantai dan berkesinambungan; dan d) peneliti melakukan identifikasi kasus-kasus tertentu melalui sejumlah informan (orang) yang dihubungi secara berantai dan berkesinambungan pula dengan tujuan untuk mendapatkan pendalaman dan cross check pandangan atas kasus tertentu, apakah ada persamaan dan perbedaan pandangan sampai informasi itu jenuh/ memiliki kecenderungan sama.

Berdasarkan fokus dan masalah yang dipilih, informan dalam penelitian adalah dibedakan menjadi 4 kelompok. Pertama, aktor penanggungjawab program yang berperan merumuskan dan sekaligus sebagai evaluator internal. Kedua, organisasi pelaksana program pada tingkat kelompok sasaran (masyarakat miskin). Ketiga, anggota masyarakat miskin sebagai sasaran program. Keempat, organisasi non pemerintah (LSM).

Data dan informasi diperoleh melalui: 1) Observasi, 2) Wawancara dan 3) penelusuran 
dokumen. Sedangkan instrumen utama penelitian ini adalah peneliti. Teknik analisis menggunakan analisis interaktif dari Miles dan Huberman (1992), yaitu pengumpulan data; reduksi data; penyajian data menjadi pola, kategori atau tema tertentu dengan narasi verbal; dan interpretasi data dengan melakukan komparasi dengan konsep dan teori yang menjadi sandaran untuk kemudian membuat kesimpulan. Analisis data dilakukan secara bersamaan dengan aktivitas pengumpulan data.

\section{HASIL DAN PEMBAHASAN \\ Deskripsi Penyebab Kemiskinan Masyarakat Kota Bandar Lampung}

Seperti telah dijelaskan pada bagian pendahuluan, 31,43\% masyarakat miskin di Kota Bandar Lampung tersebar di 13 kecamatan. Hasil identifikasi survey yang dilakukan TKPK-D dan TKMPK-D Provinsi Lampung seperti pada Tabel 1 menemukan bahwa kemiskinan yang dialami Rumah Tangga Miskin disebabkan oleh beberapa hal. Pertama, $40 \%$ disebabkan oleh sempitnya peluang kerja dan pengangguran. Kedua, $17,7 \%$ disebabkan oleh minimnya kualitas sdm, khususnya keterampilan dan pengetahuan yang menunjang kewirausahaan. Ketiga, 7,3\% disebabkan oleh ketiadaan modal untuk memulai usaha sendiri. Keempat, 15,7\% disebabkan oleh rendahnya akses finansial dari lembaga keuangan, pemerintah dan koperasi. Kelima, 17,7\% disebabkan oleh kerja serabutan atau kerja tidak tetap atau buruh lepas tanpa perlindungan. Keenam, $1,6 \%$ disebabkan oleh isolasi karena minimnya atau ketiadaan infrastruktur.

Tabel 1: Penyebab Kemiskinan Masyarakat Perkotaan di Lokasi PNPM MP Bandar Lampung

\begin{tabular}{|c|c|c|}
\hline No & Penyebab Kemiskinan & $\%$ \\
\hline 1 & Sempitnya Peluang Kerja dan pengangguran & 40 \\
\hline 2 & $\begin{array}{l}\text { Minimnya kualitas SDM (skil dan } \\
\text { pengetahuan khusus) }\end{array}$ & 17.7 \\
\hline 3 & $\begin{array}{l}\text { Ketiadaan modal untuk memulai usaha } \\
\text { sendiri }\end{array}$ & 7.3 \\
\hline 4 & $\begin{array}{l}\text { Rendahnya akses finansial dari lembaga } \\
\text { keuangan, pemerintah dan koperasi }\end{array}$ & 15.7 \\
\hline 5 & $\begin{array}{l}\text { Kerja serabutan/tidak tetap/buruh lepas tanpa } \\
\text { perlindungan }\end{array}$ & 17.7 \\
\hline 6 & $\begin{array}{l}\text { Isolasi karena minimnya atau ketiadaan } \\
\text { infras truktur }\end{array}$ & 1.6 \\
\hline Total & & 100 \\
\hline
\end{tabular}

Sumber: Laporan hasil survey TKPK-D dan TKMPK-D Provinsi Lampung, 2010

Bila data pada Tabel 1 dikomparasikan dengan jumlah penduduk miskin di Kota Bandar yang mencapai 276.474 jiwa dan status pekerjaan seperti terlihat pada Tabel 2, maka dapat dijelaskan 3 hal pokok. Pertama, penyebab kemiskinan yang utama adalah karena pengangguran, sebanyak 46.107 jiwa. Kedua, kemiskinan yang disebabkan minimnya penghasilan, sebanyak 230.367 jiwa (276.47446.104 jiwa) atau 61,5\%. Ketiga, sebanyak 143.894 jiwa atau 38,5\% dari keseluruhan masyarakat yang bekerja (374.261 jiwa) yang mampu mendapatkan penghasilan layak.
Tabel 2: Jumlah Penduduk Kota Bandar Lampung Yang Berumur 15 Tahun Ke Atas Berdasarkan Status Pekerjaan

\begin{tabular}{ccccc}
\hline No. & $\begin{array}{c}\text { Status Pekerjaan Penduduk } \\
\text { Yang Berumur 15 tahun ke atas }\end{array}$ & Jumlah & Persentase Rasio \\
\hline 1 & Bekerja & 374.261 & 89 & 8 \\
2 & Pengangguran & 46.107 & 11 & 1 \\
& Grand Total & 420.368 & 100 & \\
\hline
\end{tabular}

Sumber: Bandar Lampung Dalam Angka dari Dinas Tenaga Kerja \& Trasmigrasi Kota Bandar Lampung. BPS Kota Bandar Lampung (2010).

Deskripsi Program Opersasional PNMP Mandiri Perkotaan di Kota Bandar Lampung

Dengan berpedoman pada jumlah dan penyebab kemiskinan masyarakat Kota Bandar Lampung, maka program yang dibuat harus tepat. Program adalah strategi untuk mencapai tujuan, artinya sebagai solusi yang ditujukan untuk memecahkan masalah substantif masyarakat miskin (kelompok sasaran) di Kota Bandar Lampung.

Aras normatif sebagaimana tertuang dalam dokumen pedoman umum Program Nasional Pemberdayaan Masyarakat Mandiri Perkotaan (PNPM MP) dari Pemerintah Pusat, ruang lingkup (cakupan) PNPM MP dirancang terbuka bagi semua kegiatan penanggulangan kemiskinan yang diusulkan dan disepakati masyarakat (opened menu program). Ruang linkup (cakupan) itu meliputi 4 (empat) program utama seperti pada Tabel 3 dibawah ini.

Tabel 3: Program Utama PNPM MP

\begin{tabular}{|c|c|c|}
\hline No. & Program & Kegiatan Utama (Fokus) \\
\hline$\overline{1}$ & $\begin{array}{l}\text { Penyediaan } \\
\text { dan perbaikan pasarana/saran } \\
\text { a lingkungan permukiman, } \\
\text { sosial dan ekonomi. }\end{array}$ & $\begin{array}{l}\text { Penyediaan } \\
\text { dan perbaikan pasarana/sarana } \\
\text { lingkungan permukiman, sosial } \\
\text { dan ekonomi melalui kegiatan } \\
\text { padat karya. }\end{array}$ \\
\hline 2 & $\begin{array}{l}\text { Penyediaan } \\
\text { sumberdaya keuangan. }\end{array}$ & $\begin{array}{l}\text { Penyediaan sumberdaya keuangan } \\
\text { melalui dana bergulir dan kredit } \\
\text { mikro untuk mengembangkan } \\
\text { kegiatan ekonomi masyarakat } \\
\text { miskin. Perhatian yang lebih } \\
\text { besar diberikan bagi kaum } \\
\text { perempuan untuk memanfaatkan } \\
\text { dana bergulir ini. }\end{array}$ \\
\hline 3 & $\begin{array}{l}\text { Peningkatan kualitas } \\
\text { sumberdaya manusia. }\end{array}$ & $\begin{array}{l}\text { Kegiatan yang terkait peningkatan } \\
\text { kualitas sumberdaya manusia, } \\
\text { terutama yang bertujuan untuk } \\
\text { mempercepat pencapaian target } \\
\text { MDGs }\end{array}$ \\
\hline 4 & $\begin{array}{l}\text { Peningkatan kapasitas } \\
\text { masyarakat dan pemerintahan } \\
\text { lokal. }\end{array}$ & $\begin{array}{l}\text { Peningkatan kapasitas masyaraka } \\
\text { dan pemerintahan lokal melalui } \\
\text { penyadaran kritis, pelatihan } \\
\text { ketrampilan usaha, manajemen } \\
\text { organisasi dan keuangan, serta } \\
\text { penerapan tata kepemerintahan } \\
\text { yang baik (good governance). }\end{array}$ \\
\hline
\end{tabular}

Sumber: Pedoman Umum PNPM MP Pemerintah Pusat, Tahun 2008

Disamping itu, secara substantif, dokumen Pedum PNPM MP Pemerintah Pusat memuat komponenkomponen utama yang terkait dengan rangkaian proses pemberdayaan masyarakat. Komponen program pokok itu, adalah:

1) Pengembangan Masyarakat yang mencakup serangkaian kegiatan untuk membangun kesadaran kritis dan kemandirian masyarakat yang terdiri dari 
pemetaan potensi, masalah dan kebutuhan masyarakat, perencanaan partisipatif, pengorganisasian, pemanfaatan sumberdaya, pemantauan dan pemeliharaan hasil-hasil yang telah dicapai. Untuk mendukung rangkaian kegiatan tersebut, disediakan dana pendukung kegiatan pembelajaran masyarakat, pengembangan relawan dan operasional pendampingan masyarakat; dan fasilitator, pengembangan kapasitas, mediasi dan advokasi. Peran fasilitator terutama pada saat awal pemberdayaan, sedangkan relawan masyarakat adalah yang utama sebagai motor penggerak masyarakat di wilayahnya.

2) Bantuan Langsung Masyarakat (BLM) merupakan dana stimulan keswadayaan yang diberikan kepada kelompok masyarakat untuk membiayai sebagian kegiatan yang direncanakan oleh masyarakat dalam rangka meningkatkan kesejahteraan terutama masyarakat miskin.

3) Peningkatan Kapasitas Pemerintah dan Pelaku Lokal yang mencakup serangkaian kegiatan untuk meningkatkan kapasitas pemerintah daerah dan pelaku lokal atau kelompok perduli lainnya. Kegiatan ini bertujuan untuk menciptakan kondisi yang kondusif, sinergi dan berimplikasi positif bagi masyarakat, terutama kelompok miskin dalam menyelenggarakan hidupnya secara layak. Kegiatan terkait dalam komponen ini diantaranya seminar, pelatihan, lokakarya, kunjungan lapangan yang dilakukan secara selektif dan sebagainya.

4) Bantuan Pengelolaan dan Pengembangan Program meliputi kegiatan-kegiatan untuk mendukung pemerintah dan berbagai kelompok peduli lain yang terlibat dalam pengelolaan program. Kegiatan-kegiatan itu meliputi penyediaan konsultan manajemen, pengendalian mutu, evaluasi dan pengembangan program.

Sementara pada sisi lain, hasil pengkajian dokumen program PNPM Mandiri Perkotaan Kota Bandar Lampung yang merupakan strategi dan langkah konkrit memperlihatkan bahwa rancangan normatif PNPM Mandiri Perkotaan Pemerintah Pusat dijabarkan (interpretasikan) kedalam program operasional penanggulangan kemiskinan dan pemberdayaan masyarakat Kota seperti tampak pada Tabel 4 dibawah ini.

Tabel 4: Penjabaran Program kedalam Bentuk Program Aksi (Fokus) sebagai Rumusan Program Utama PNPM MP Kota Bandar Lampung

\begin{tabular}{|c|c|c|}
\hline No. & $\begin{array}{c}\text { Program Acuan dari Pemerintah } \\
\text { Pusat }\end{array}$ & $\begin{array}{l}\text { Penjabaran Program kedalam Bentuk Program } \\
\text { Aksi (Fokus) }\end{array}$ \\
\hline 1 & $\begin{array}{l}\text { Penyediaan } \\
\text { dan perbaikan infrastruktur } \\
\text { (sarana/prasarana) lingkungan } \\
\text { permukiman }\end{array}$ & $\begin{array}{l}\text { Penyediaan dan perbaikan infrastruktur } \\
\text { (sarana/prasarana) lingkungan permukiman } \\
\text { melalui kegiatan padat karya. }\end{array}$ \\
\hline 2 & $\begin{array}{l}\text { Penyediaan } \\
\text { dan perbaikan infrastruktur } \\
\text { (sarana/prasarana) sosial }\end{array}$ & $\begin{array}{l}\text { Penyediaan dan perbaikan infrastruktur } \\
\text { (sarana/prasarana) sosial melalui kegiatan padat } \\
\text { karya. }\end{array}$ \\
\hline 3 & $\begin{array}{l}\text { Penyediaan } \\
\text { dan perbaikan infrastruktur } \\
\text { (sarana/prasarana)ekonomi }\end{array}$ & $\begin{array}{l}\text { Penyediaan dan perbaikan infrastruktur } \\
\text { (sarana/prasarana) ekonomi melalui kegiatan } \\
\text { padat karya. }\end{array}$ \\
\hline
\end{tabular}

Sumber: Dokumen PNPM MP Kota Bandar Lampung, 2007-2011.
Mencermati Tabel 4 diatas, maka sesungguhnya tidak ada perbedaan antara program PNPM Mandiri Perkotaan dan program aksi sebagai rumusan program utama yang merupakan hasil penjabaran program acuan dari pemerintah pusat. Perbedaan yang terlihat hanya pada dimensi pelaksanaan program aksi melalui kegiatan padat karya.

Peneliti juga berhasil mendapatkan informasi mengenai pengalokasian dana dan kegiatan PNPM MP Kota Bandar Lampung. Dana PNPM MP tahun 2006 dialokasikan untuk membiayai beberapa kegiatan. Pertama, 70\% untuk pembangunan dan perbaikan infrastruktur umum, seperti perbaikan jalan lingkungan RT dan jalan lingkungan perumahan yang baru diserahkan pihak pengembang kepada pemerintah kota. Kedua, 10\% untuk pembangunan dan perbaikan infrastruktur sosial, seperti renovasi rumah ibadah, dan bantuan langsung tunai untuk kegiatan sosial melalui pemberian dana kepada pengelola yayasan untuk merpebaiki panti asuhan, rumah jompo dan pembelian kebutuhan penghuni rumah jompo dan anak-anak binaan panti asuhan. Ketiga, $20 \%$ untuk pembiayaan kegiatan ekonomi produktif, khususnya pinjaman modal dengan kredit berbunga ringan, seperti pinjaman modal kepada beberapa pengembang industri rumah tangga pengembangan aneka kripik di wilayah Kecamatan Tanjungkarang Barat. Lebih lanjut, pada tahun 2007 hingga tahun 2011 terjadi perubahan komposisi alokasi anggaran PNPM MP Kota Bandar Lampung. Anggaran hanya ditujukan pada 2 unsur tridaya, yaitu pembangunan dan perbaikan infrastruktur umum sebesar $80 \%$; dan pembangunan dan perbaikan infrastruktur sosial (20\%), sementara unsur ekonomi tidak mendapat perhatian sama sekali. Dari total anggaran PNPM MP Kota Bandar Lampung mulai tahun 2006 hingga tahun 2011, komposisi alokasi anggaran adalah 79,3\% untuk infrastruktur umum; 19,83\% untuk infrastruktur sosial; dan $0.87 \%$ untuk unsur ekonomi.

Bila deskripsi diatas dikaitkan dengan penyebab kemiskinan masyarakat Kota Bandar Lampung seperti tertera pada Tabel 1, maka semestinya program aksi sebagai rumusan program utama PNPM MP Kota Bandar Lampung lebih fokus pada upaya: (a) untuk membuka peluang kerja dan mengatasi persoalan penggannguran; (b) peningkatan kualitas sdm, khususnya program-program yang bersentuhan langsung dengan peningkatan skil dan pengetahuan masyarakat miskin, misalnya diklat perbengkelan, pertukangan, kerajinan, dll; (c) memperbesar bantuan permodalan bagi masyarakat yang telah mempunyai keahlian dan usaha tetap untuk mengembangkan usahanya dengan pendampingan, pembinaan aspek manajerial dan jaringan pemasaran; (d) programprogram perlindungan buruh migran dan kegiatan aksi untuk memproteksi buruh dan keluarganya, misalnya dalam aras makro dan jangka panjang, pemerintah perlu membuat rancangan upah minimum yang memadai, sementara dalam aras mikro, dapat melakukan kerjasama dengan pihak ketiga untuk membuat rancangan program asuransi ketenaga-kerjaan dan 
perlindungan hari tua para buruh (masyarakat miskin); (e) pemerintah kota perlu menyiapkan program yang secara langsung berkenaan dengan upaya peningkatan akses finansial masyarakat miskin kepada lembaga keuangan, pemerintah dan koperasi, misalnya pemberian akses kredit berbunga rendah tanpa jaminan, pembentukan lembaga keuangan masyarakat dengan penyertaan modal dari pemerintah; atau upaya lain yang mengarah kepada terbentuknya lembaga keuangan bagi masyarakat miskin; dan (f) program aksi yang mengarah pada upaya membuka isolasi kewilayahan di daerah pemukiman masyarakat miskin karena minimnya atau ketiadaan infrastruktur, seperti masyarakat nelayan yang tinggal di wilayah pesisir pantai dan petani yang tinggal di beberapa pulau kecil.

Sayangnya program operasional PNPM Mandiri Perkotaan Kota Bandar Lampung bila dikaji dari sisi substansi masih banyak diarahkan kepada renovasi fasilitas (infrastruktur) umum. Artinya program demikian ini lebih bersifat umum pula yang dimikmati oleh semua pihak warga kota tanpa terkecuali, tidak ada nilai kekhususan program yang benarbenar ditujukan kepada warga miskin kota. Dengan demikian, dapat dikatakan bahwa program aksi yang dijalankan belum belum menyentuh akar persoalan (kemiskinan) yang dialami masyarakat miskin target group PNPM MP Kota Bandar Lampung. Program hanya mengatasi fenomena (gejalah) yang muncul atau 'symptomatic program' dan belum mengarah kepada 'strategic program'. Arah program lebih kepada kegiatan pembangunan fisik (infrastruktur), sedangkan dimensi pemberdayaan ekonomi belum terjamah. Kalaupun ada tercakup dalam program penyediaan dan perbaikan infrastruktur ekonomi yang tidak memiliki keterkaitan secara langsung. Dengan demikian program operasional belum beorientasi atau berpihak pada rakyat miskin sebagai sasaran (pro poor policy), tetapi masih menunjukkan kehendak dan keinginan pemerintah.

Deskripsi Pelembagaan (Forum) Musyawarah Perumusan dan Implementasi Program Opersasional PNMP Mandiri Perkotaan di Kota Bandar Lampung

Reformasi merupakan perubahan ke arah kondisi yang lebih baik. Sejalan dengan hal ini, maka reformasi yang terjadi di Indonesia sejatinya harus mampu memproduksi kebijakan yang merupakan solusi atas akar persoalan, yaitu penyebab kemiskinan. Pada titik inilah mengindikasikan adanya tekad kuat (political will) pemerintah untuk mewujudkan tata-kelola institusi publik yang lebih demokratis (democratic governance) sesuai hakekatnya dari, oleh dan untuk rakyat.

Reformasi merupakan pintu masuk dan tonggak perubahan nilai dari government ke governance, dan dari sentralisasi kearah desentralisasi serta pada akhirnya akan tercipta kerjasama antara pemerintah dan masyarakatnya melalui pelembagaan (forum) musyawarah untuk merumuskan dan menjalankan program atas kesepakatan bersama; atau kendati tidak sama persis akan diperoleh output kebijakan deliberatif untuk mengatasi persoalan yang sedang dialami masyarakat. Reformasi telah memberikan ruang publik, yaitu untuk terjadinya dialog antara pemerintah dengan warga dan berkembangnya wacana publik nyata bukan lagi hanya sekedar dominasi 'diskursus pemerintah' seperti yang sering terjadi sebelumnya. Ruang dimana semua unsur policy stakeholder bertemu secara intens, mendiskusikan dan membahas semua persoalan dan menentukan tindakan atau langkah yang perlu diambil bersama untuk memperbaiki kondisi sosial-ekonomi warga kota. Hal inilah yang merupakan esensi pokok musyawarah-mufakat antara semua stakeholders yang ada, atau paling tidak antara pemerintah, warga miskin kota dan lembaga-lembaga yang menaruh perhatian terhadap persoalan kemiskinan.

Dalam perspektif governance, administrasi publik bukan lagi sebatas domainnya lembaga pemerintah, tetapi meliputi semua lembaga yang misi utamanya mewujudkan publicness. Organisasi semacam ini tidak lain adalah organisasi yang peduli pada shared problems dan beroperasi untuk mencapai public purposes. Karenanya, perencanaan, implementasi dan bahkan evaluasi program menuntut partisipasi aktif warga. Artinya, konsep publik dalam administrasi publik tidak lagi diartikan hanya semata-mata tertuju kepada lembaga (institusi) pemerintah tetapi lebih pada bagaimana orientasi dan nilai-nilai publicness dapat berjalan dengan baik (Pesch, 2008).

Sejalan dengan uraian diatas, maka pada ranah kebijakan publik, perkembangan-perkembangan itu berimplikasi pada semakin meluasnya medan kebijakan yang memungkinkan aktor-aktor non negara, seperti warga, pihak swasta dan LSM untuk berpartisipasi, ambil bagian atau terlibat secara aktif. Konsep inilah yang pada sesi perkembangan lebih lanjut, merumuskan makna kebijakan sebagai hasil dari interaksi berbagai aktor yang memiliki kepentingan dan strategi yang kompleks (Klijn \& Koppenjan 2000). Dalam konteks ketika negara bukanlah satusatunya agen perumus dan implementor (planning and implementing agency) suatu kebijakan publik, fungsi steering terhadap hubungan-hubungan para aktor yang kompleks dalam memformulasikan, mengambil keputusan maupun implementasi kebijakan publik tersebut menjadi sangat sentral. Tentu kondisi ini sesuai dengan 'governance without government' dari Rosenau dan Czempriel (1992) sebagi sebuah metafor untuk menggambarkan meluasnya kekuasaan dan terbatasnya peran dan kapasitas pemerintahan saat ini. Pemikiran yang demikian ini telah menempatkan perlunya pelembagaan (forum) musyawarah diantara policy stakeholders untuk mencapai kemufakatan dan bekerjasama merumuskan, menjalankan dan mengevaluasi program yang disepakati bersama.

Frame governance memandang bahwa administrasi publik didefinisikan sebagai proses penggunaan kekuasaan administratif, politik, dan ekonomi untuk menyelesaikan masalah-masalah publik (Dwiyanto 2004:17). Kelembagaan administrasi publik tidak lagi terbatas pada lembaga-lembaga pemerintah, tetapi bisa melibatkan lembaga-lembaga lainnya, seperti 
mekanisme pasar dan organisasi masyarakat sipil (civil society organization). Semua lembaga, baik pemerintah maupun non pemerintah, menjadi subyek untuk merespon masalah dan kepentingan publik (public affairs and public interests).

Paradigma inilah berhasil menggeser lokus ilmu administrasi publik selama ini, yaitu pergeseran dari birokrasi pemerintah menjadi masalah dan kepentingan publik (public interests and public affairs), namun tetap menempatkan lembaga pemerintah sebagai satusatunya institusi yang memiliki otoritas dalam proses pengambilan kebijakan publik dengan membuka ruang selebar-lebarnya bagi partisipasi publik. Partisipasi kelompok-kelompok stakeholders dalam proses kebijakan publik sangat diperlukan. Dengan cara ini, proses kebijakan publik bukan hanya menjadi lebih partisipatif, tetapi tentu dengan sendirinya akan menjadi lebih responsif dan akuntabel. Uraian ini sesuai pula dengan pernyataan Bovaird \& Loffler (2003:166167) yang mengemukakan tentang perubahan peran pemerintah dari policy making menjadi policy moderating.

Dalam konsepsi ini, prinsip-prinsip partisipasi, transparansi, akuntabilitas, rule of law, responsif, berorientasi pada konsensus, equity serta inclusiveness menjadi fondasi penting bagi tegaknya governance. Dengan kata lain, kata kunci governance adalah consensus building dan akomodasi kepentingan sebagai basis untuk membangun sinergi. Dalam pengertian ini, selain mengandaikan pada bekerjanya lembaga negara secara baik, definisi ini juga mendorong pada penguatan lembaga-lembaga pasar dan civil society. Kondisi ini adalah prasyarat agar fungsi-fungsi akomodasi kepentingan dan membangun konsensus dari governance bisa berjalan seimbang. Di sini, hubungan-hubungan kekuasaan antara negara, pasar dan masyarakat menjadi relatif otonom dan horisontal. Implikasinya, proses-proses negosiasi kepentingan (bukannya regulasi) menjadi sentral dalam setiap perumusan, pengambilan, dan implementasi kebijakan publik (Pierre dan Peters 1998).

Berdasarkan uraian diatas, proses partisipasi masyarakat Kota Bandar Lampung dalam perumusan program operasional PNPM Mandiri Perkotaan Kota Bandar Lampung dilakukan melalui wadah LKM dan KSM yang masih sangat 'top down' dan sentralistis. Hal ini tercermin dalam Surat Keputusan Menteri Pekerjaan Umum Nomor: 358/KPTS/M/2008 yang menyatakan Organisasi Pelaksana merupakan suatu bagian yang tidak terpisahkan dari pengelolaan dan penyelenggaraan Program Nasional Pemberdayaan Masyarakat Mandiri Perkotaan yang dilakukan secara berjenjang dari tingkat nasional sampai tingkat kelurahan. Dalam nomenklatur (dokumen PNPM MP) mengenai organisasi pelaksana program pada tingkat masyarakat ini, LKM dan KSM dinyatakan sebagai 'organization for supporting program' (organisasi pendukung program) pada tingkat kelurahan untuk menghimpun Kelompok Swadaya Masyarakat (KSM) pada tingkat Rukun Warga (RW) dan Rukun Tetangga. Secara normatif, pemerintah mengharapkan bahwa eksistensi LKM dan KSM mampu menjadi perencana (formulator) dalam mengidentifikasi permasalahan, kebutuhan, penentu, pelaksana dan sekaligus pemanfaat program. Tetapi harapan pemerintah itu sulit terwujud, karena istilah pada nomenklatur ini memberi implikasi: (1) eksistensi LKM dan KSM hanya pendukung, bukan pemeran utama; dan (2) kendali atau otoritas sepenuhnya masih dipegang oleh pemerintah.

Observasi terhadap musyawarah masyarakat yang membentuk LKM dan KSM semakin membuktikan dan memperkuat bahwa proses pembentukan dan eksistensi LKM dan KSM adalah bersifat top down dan lebih mengutamakan tujuan serta kepentingan pemerintah. Kemudian, dari komposisi personel (pengurus) yang mengisi keanggotaan LKM dan KSM berasal dari elit di tingkat kelurahan (RW dan RT), demikian juga dengan background personel kebanyakan bekerja sebagai PNS, pensiunan dan pihak-pihak yang secara ekonomi mampu maupun secara sosial mempunyai kedudukan terpandang dan mempunyai jenjang pendidikan yang cukup (SMA dan Perguruan Tinggi). Artinya LKM dan KSM itu merupakan representasi elit, bukan merupakan representasi masyarakat miskin sebagai target group PNPM MP yang sesungguhnya (miskin ekonomi, sosial dan politik).

Pola-pola top down itu tampak pula, bila kita mengamati struktur organisasi pelaksana PNPM MP sesuai SK Menteri PU Nomor: 358/KPTS/M/2008 melingkupi LKM dan KSM, struktur LKM, tupoksi dan hasil kerja LKM yang secara berjenjang harus dilaporkan secara priodik dengan menggunakan tata cara sesuai SOP pemerintah kepada PJOK (kecamatan dan kelurahan). Sedangkan KSM tidak lebih dari kepanitiaan yang menjadi pelaksana kegiatan pembangunan dan perbaikan infrastruktur di tingkat wilayah RT atau RW tempat masyarakat bermukim. Kegiatan pembangunan dan perbaikan infrastruktur di tingkat wilayah RT atau RW bukan hanya sekedar milik (dinikmati/diperuntukan) bagi anggota KSM saja sebagai pemetik manfaat, tetapi seluruh anggota masyarakat RT/RW, bahkan untuk semua warga.

Sebutan organisasi pelaksana program pada tingkat masyarakat dengan istilah lembaga kepemimpinan masyarakat tidak lebih dari sebuah 'kata-kata pemanis' (lip service), walaupun pemerintah menyatakan konsep LKM sebagai lembaga kepemimpinan kolektif atau sering juga mereka istilahkan 'dewan pembangunan' untuk menghindari kooptasi (kekuasaan) individu terhadap program. Faktanya dewan pembangunan tidak menjadi 'dewa' masyarakat miskin dan marginal (target group) yang semestinya menjadi pusat perhatian, bahkan ekstrimnya program khusus yang dibuat itu menjadi milik dewan pembangunan dan kroninya, semestinya menjadi milik masyarakat miskin (pro poor program, pro poor budget dan pro poor institution).

Dari aspek penentuan program, proses dan mekanisme partisipasi publik tidak terjadi dimana program-program operasional sudah dibuat dan disiapkan terlebih dahulu oleh pemerintah. Pemerintah 
dengan bantuan Tim Manajemen (konsultan) PNPM Mandiri Perkotaan menyebarkan angket isian tentang program-program yang akan diusulkan oleh warga, namun tidak boleh menyimpang dari unsur tridharma program yang telah ditetapkan. Pendek kata, warga hanya memilih program yang telah ditentukan pemerintah, bukan berperan sebagai perencana program sesuai kebutuhan masing-masing warga.

Penelitijuga menemukan fakta bahwakenyataannya LKM dan KSM selalu berganti setiap tahunnya, baik kelembagaan maupun personelnya karena program dan kegiatan yang dilakukan baik secara substansi maupun tempat berbeda. Artinya, prinsip mengenai sustainable (keberlanjutan) kelembagaan (LKM dan KSM) tidak ada. Setelah program dan kegiatan selesai, maka berakhir pula LKM dan KSM. Dengan demikian, maka lembaga kepemimpinan masyarakat yang secara normatif harus mengakar, representatif, dipercaya dan dibentuk melalui kesadaran masyarakat untuk menggali kembali nilai-nilai luhur kemanusiaan dan nilai-nilai kemasyarakatan sebagai pondasi modal sosial kehidupan masyarakat miskin memberdayakan diri secara berkelanjutan tentu tidak pernah terwujud.

Tataran implementatif program PNPM MP Kota Bandar Lampung diperuntukan untuk semua lapisan masyarakat tanpa memberikan skala prioritas pada kelompok miskin. LKM dan KSM yang dibentuk dibentuk oleh pemerintah kota tidak lebih dari sekedar LSM 'plat merah'. Mekanismenya ditentukan berdasarkan SOP pemerintah dan komposisi personilnya (keanggotaannya) terdiri dari para perangkat RT/RW, PNS, pensiunan dan elit masyarakat yang lainnya yang secara sosial maupun ekonomi terbilang mampu (berdaya). LKM dan KSM cerminan representasi elit (elitis) dengan mekanisme pembentukan bersifat top down dan bukan representasi masyarakat miskin. LKM dan KSM hanya merupakan instrumen perpanjangan tangan pemerintah untuk menyelesaikan proyek, tujuan dan kepentingan internal pemerintah, bahkan terkesan kental dengan aroma politis, seperti pernyataan salah satu aktivis Bandar

\section{Lampung Policy Watch.}

Deskripsi empiris diatas sangat bertolak belakang dengan konsep Farazmand (2004:11) yang menyatakan inti dari governance adalah partisipasi, seperti tampak pada kutipan berikut ini:

Governance here means a participatory process of governing the social, economic, and political affairs of a country, state, or local community through structures and values that mirror the society. It includes the state as an enabling institution, the constitutional framework, the civil society, the private sector, and the international/global institutional structure within limits. Here, governance is used as a broader concept than the traditional, unilateral, and authoritative forms of government whose governing elites sit on in unilateral commanding positions.

Lebih lanjut Farazmand (2004) mengemukakan bahwa partisipasi diperlukan untuk memperkuat posisi sound governance untuk dapat menghasilkan inovasi kebijakan yang secara nyata mampu menghadapi secara efektif perubahan lingkungan sistemik yang terjadi. Oleh karenanya, partisipasi publik akan tumbuh, berkembang dan menjadi kuat bila ada effective partnership, seperti tertuang dalam kutipan berikut ini.

One of the most important developments in contemporary politics and administration is the building of effective partnerships for sound governance around the world (Farazmand 2004:77). Partnership, therefore, has become a central requirement of good governance and sound governance in the contemporary global environment (Farazmand 2004:79).

Sebagai penjabaran lebih lanjut, Farazmand (2004:81) mengemukan: Partnership implies joint and voluntary endeavors toward a common purpose. In the context of sound governance, partnership is essential and requires genuine participation of the stakeholders, meaning all citizens who have stakes in the governance process.

Jadi esensi penting dari governance adalah partisipasi, inisiasi, responsif dan akuntabel, serta kesemua ini akan bisa dicapai melalui kemitraan. Kemitraan antar stakeholders menjadi prasyarat terpenting bagi terbentuknya sound governance yang efektif.

Kaitan antara operasionalisasi good governance dalam ranah kebijakan oleh Hajer dan Wagenaar (2003:7) diberi nama deliberative policy analysis dimana inspirasi ini dikembangkan dari pemikiran Frank Fischer dan John Forester dalam karyanya The Argumentative Turn in Policy Analysis and Planning (1993), seperti pada kutipan berikut ini:

"... and solid work in planning theory demonstrated how planners in concrete situations of conflict relied on interactive and deliberative and giving reasons, exploring the implications of various value positions, and developing joint responsibility in concrete situations".

Dengan demikian deliberative policy merupakan model pendekatan kebijakan yang menekankan pada 'network society' dan hal ini sejalan dengan 'collaborative policy making: governance through dialogue' dari Judith E. Innes dan David E. Booker yang dikutif oleh Hajer dan Wagenaar (2003), atau mungkin dalam konteks Indonesia dikenal dengan model musyawarah. Pemerintah dan legislatif hanya berperan sebagai fasilitator dan legislator, sementara masyarakat melalui kelembagaan formalnya yang aktif mengidentifikasi persoalan, merancang dan mengajukan program yang dibutuhkan kepada aktor formal pemerintah.

Pergeseran model ini telah mempertegas fungsi desentralisasi untuk mengakomodasi kemajemukan aspirasi masyarakat lokal, adanya penyadaran tentang variasi kehendak politik (political variety) untuk menyalurkan suara dan pilihan (kepentingan) masyarakat lokal yang pastinya akan difasilitasi dengan mempertimbangkannya sebagai input perumusan kebijakan dan menghasilkan kebijakan (program) nyata yang benar-benar mencerminkan kehendak masyarakat. 
Mencermati hasil telaah diatas, maka dapat dinyatakan pelembagaan (forum) musyawarah yang dilakukan baik dalam perumusan maupun pelaksanaan program aksi PNPM MP di Kota Bandar Lampung masih terkategori simbolik. Forum musyawarah masih dikondisikan oleh pemerintah melalui LKM dan KSM dengan keanggotaan cerminan representasi elit (elitis) dan mekanisme pembentukan bersifat top down dan bukan representasi masyarakat miskin. Forum musyawarah yang dibentuk tidak lebih dari sekedar LSM 'plat merah'. Hal inilah yang menjadi penyebab kegagalan PNPM MP di Kota Bandar Lampung dalam mengatasi persoalan kemiskinan warga kota, dimana program aksi baru mampu mengatasi fenomena (gejalah) yang muncul atau 'symptomatic program' dan belum mengarah kepada 'strategic program'. Program operasional belum beorientasi atau berpihak pada rakyat miskin sebagai sasaran (pro poor policy), tetapi masih menunjukkan kehendak dan keinginan pemerintah. Hal ini disebabkan oleh dalam proses perumusan program operasional PNPM Mandiri Perkotaan Kota Bandar Lampung, pemerintah belum membuka pintu seluas-luasnya bagi terciptanya interaksi, dialog, partisipasi publik dan belum adanya kemitraan yang terbangun antara pemerintah, warga dan stakeholders lain yang memungkinkan. Dengan demikian, dari perspektif governance, PNPM Mandiri Perkotaan Kota Bandar Lampung bukanlah sebuah kebijakan deliberatif, tetapi masih merupakan 'in policy', yaitu kebijakan inkremental, tambal-sulam atas kebijakan sebelumnya dan lebih mencerminkan kepentingan pemerintah.

\section{SIMPULAN DAN SARAN}

LKM dan KSM merupakan bentuk pelembagaan (forum) musyawarah dalam permusan dan implementasi program operasional PNPM Mandiri Perkotaan di Kota Bandar Lampung. Forum ini masih bersifat simbolik. Artinya forum musyawarah masih dikondisikan oleh pemerintah dengan mekanisme pembentukan bersifat top down, keanggotaannya cerminan representasi elit (elitis) bukan representasi masyarakat miskin dan demikian pula dengan keikutsertaan warga masih terkesan sebagai partisipasi semu. Kondisi inilah yang menyebabkan substansi program aksi PNPM MP di Kota Bandar Lampung belum menyentuh akar persoalan kemiskinan warga kota. Program aksi baru mampu mengatasi fenomena (gejalah) yang muncul atau 'symptomatic program' dan belum mengarah kepada 'strategic program'. Program operasional belum beorientasi atau berpihak pada rakyat miskin sebagai sasaran (pro poor policy), tetapi masih menunjukkan kehendak dan keinginan pemerintah. PNPM Mandiri Perkotaan Kota Bandar Lampung belum menunjukan program aksi (kebijakan) hasil dari pelembagaan (forum) musyawarah atau sebagai hasil proses deliberasi, tetapi lebih merupakan 'in policy', yaitu kebijakan inkremental, tambal-sulam atas kebijakan sebelumnya dan lebih mencerminkan kepentingan pemerintah.
Sehubungan dengan kondisi diatas, maka ada dua saran yang menjadi masukan untuk ditindak-lanjuti oleh pemerintah kota guna meningkatkan kualitas kebijakan (program), yaitu: (1) perlu merumuskan rancangan kelembagaan (forum) musyawarah yang benar-benar mencerminkan hakekat musyawarah yang sesungguhnya dengan dilandasi kerangka legal formal yang mengatur partisipasi publik kedalam bentuk perencanaan partisipatif; dan (2) perlu menumbuhkembangkan nilai-nilai demokrasi perencanaan melalui kerjasama nyata, pembinaan manajerial, dukungan finansial dan penguatan jejaring (networking) kemitraan dengan organisasi akar rumput sebagai wadah masyarakat.

\section{DAFTAR PUSTAKA}

Bovaird, T \& Loffler, E (ed.) 2003. Public Management and Governance. London: Routledge.

Dwi Yanto, Agus. 2004 Gajah mada Universitty prees. Yogyakarta 2004. Mewujudkan Good Governance melalui pelayanan publik,

Farazmand, A (ed). 2004. Sound Governance: Policy and Administrative Innovations. Westport Connecticut: Praeger Publishers.

Klijin. E.H; Koppejan, J.F.M ; 2000. Public management and polcy networks: Foundations of a network approach to govermance.

Miles, M. dan Huberman, A.M. 1992. Analisis Data Kualitatif. Terjemahan Tjetjep Rohandi Rohidi. Jakarta: UI Press.

Pesch, U. 2008. The publicness of public administration. Administration \& Society 40(2):170- 193.

Pieere, J \& Peters. BG (2000) Governance, Politics and the state New York St. Martin'S Prees

Rosenau: Czem Priel Otto 1992 . Govermance. Without Government : order and change in world

Laporan dan Dokumentasi:

BPS Propinsi Lampung. 2010. Angka Kemiskinan Propinsi Lampung.

BPS Bandar Lampung. 2010. Bandar Lampung Dalam Angka.

Bappeda Kota Bandar Lampung. Laporan Kemajuan PNPM MP Kota Bandar Lampung. Tahun 20092011.

Bappeda Kota Bandar Lampung. 2010. Dokumen PNPM MP Kota Bandar Lampung tahun 20062011.

TKPK-D dan TKMPK-D Provinsi Lampung. 2010. Laporan Hasil Survey Kemiskinan Warga Perkotaan.

Kemenkokesra. 2008. Pedoman Umum PNPM Mandiri Perkotaan. 